Riski Fauziah, Jekti Prihatin, Suratno. (2018). Pengaruh Pemberian Pupuk ZA pada Tanaman Murbeu terhadap Kokon Ulat Sutera Alam. Vol. 4 (1) Pp. 37-41. Doi: https://doi.org/10.23917/bioeksperimen.v4i1.2802

\title{
Pengaruh Pemberian Pupuk ZA pada Tanaman Murbei terhadap Kokon Ulat Sutera Alam
}

\author{
Riski Fauziah*, Jekti Prihatin, Suratno \\ Pendidikan Biologi Jurusan Pendidikan MIPA Fakultas Keguruan dan Ilmu Pendidikan, Universitas Jember \\ Jalan Kalimantan 37, Jember 68121 \\ *Email : riskifauziah19@gmail.com
}

\begin{abstract}
$Z A$ fertilizer is an inorganic fertilizer which contains nitrogen and sulfur. Nitrogen is the main nutrient of plant growth which is classified as protein composer, while sulfur is the composer of 21 amino acids that composes protein. Protein is needed by Bombyx mori L. for its body's metabolism and for the cocoon's formation. The research aims to explore the influence of $Z A$ fertilization of mulberry on naturan silkworm's (B.mori) cocoon. The mulberry which is fertilized with $Z A$ is a month old since the planting's date, and is used as feed after 3 months old since the planting's date. The type of research is descriptivequantitative research. The result shows the existence of influence of mulberry with $Z A$ fertilization on on the cocoon's weight $(F=8.767, p=0.000)$ and the cocoon's diameter $(F=2.914, p=0.036)$. The average of the heaviest cocoon is $P 3(18,75 \mathrm{~g} /$ polybag) with average $1.91 \mathrm{gr}$. The average of the cocoon's highest diameter is P3 (18,75 g/polybag) with average $2.08 \mathrm{~cm}$.
\end{abstract}

Keywords: Cocoon, ZA fertilizer, natural silkworm (Bombyx mori L.).

\section{Abstrak}

Pupuk ZA merupakan pupuk anorganik yang mengandung nitrogen dan sulfur. Nitrogen merupakan unsur hara utama pada pertumbuhan tanaman yang merupakan penyusun protein, sedangkan sulfur merupakan penyusun 21 asam amino pembentuk protein. Protein dibutuhkan oleh Bombyx mori L. untuk metabolisme dalam tubuhnya serta untuk pembentukan kokon. Tujuan penelitian ini yaitu untuk mengetahui pengaruh pemberian pupuk ZA pada tanaman murbei terhadap kokon ulat sutera alam (B. mori). Tanaman murbei yang diberi perlakuan pupuk ZA berumur 1 bulan dari penanaman, dan digunakan sebagai pakan setelah berumur 3 bulan dari penanaman. Jenis penelitian ini yaitu deskriptif kuantitatif. Hasil penelitian menunjukkan terdapat pengaruh tanaman murbei yang diberi pupuk ZA terhadap berat kokon $(\mathrm{F}=8,767, \mathrm{p}=0,000)$ dan diameter kokon $(\mathrm{F}=2,914, \mathrm{p}=0,036)$. Rerata berat kokon tertinggi yaitu pada P3 (18,75 g/polybag) dengan rerata 1,91 g. Rerata diameter kokon tertinggi pada P3 (18,75 g/polybag) dengan rerata $2,08 \mathrm{~cm}$.

Kata kunci: Kokon, pupuk ZA, ulat sutera alam (Bombyx mori L.).

\section{Pendahuluan}

Ulat sutera alam (Bombyx mori Linn.) merupakan salah satu jenis serangga dari Ordo Lepidoptera yang mengalami metamorfosis sempurna (Atmosoedarjo et al., 2000). Pada akhir fase larvanya dapat membentuk kokon berupa serat sutera. Sutera menjadi bahan baku industri tekstil, parasut, dan lain sebagainya (Nuraeni et al., 2007). Namun, produksi benang sutera Indonesia belum memenuhi kebutuhan. Upaya pemenuhan kebutuhan tersebut dilakukan dengan meningkatkan pemeliharaan ulat sutera (Setiadi et al., 2011). Menurut Widiyaningrum (2009), salah satu faktor yang harus diperhatikan untuk meningkatkan produktivitas ulat sutera yaitu manajemen pemberian pakan.

Pakan utama bagi ulat sutera alam yaitu daun murbei. Jumlah serta mutu daun mempengaruhi kesehatan ulat, produksi, dan kualitas kokon yang dihasilkan. Baik secara langsung maupun tidak langsung akan berpengaruh terhadap kualitas dan kuantitas benang sutera yang dihasilkan (Rahmayanti et al., 2008). Daun murbei memiliki peran penting terhadap pertumbuhan dan perkembangan ulat sutera alam. Menurut Setiadi $e t$ 
al, (2011), salah satu kendala usaha tani persuteraan alam di Indonesia yaitu produktivitas kebun murbei yang masih rendah. Hal ini tentu akan berpengaruh terhadap produksi kokon dan menghambat jumlah produktivitas ulat sutera.

Kualitas daun murbei dipengaruhi oleh kondisi tanah, derajat keasaman, serta lama mendapat sinar matahari. Struktur atau kondisi tanah untuk kebun murbei dapat dipertahankan kesuburannya dengan menggunakan pupuk hijau, pupuk kandang, serta bahan organik lain sebagai sumber humus (Rahmayanti et al., 2008). Pemupukan merupakan usaha intensifikasi pertanian, dengan tujuan untuk menambah persediaan unsur hara yang dapat meningkatkan produksi serta mutu hasil tanam. Pupuk yang dapat digunakan antara lain yaitu pupuk organik (pupuk kandang atau kompos) dan pupuk anorganik (Urea, KCl, TSP, serta ZA). Penelitian sebelumnya yang dilakukan oleh Kar etal. (2013), menggunakan ES (Elemental sulphur) dan AS (Ammonium sulphate) untuk memupuk murbei (Morus alba L.), hasilnya dengan perlakuan ES daun murbei memiliki lebar daun maksimal dengan dosis pupuk $30 \mathrm{~kg}$ ha/tahun dan pada perlakuan AS, lebar daun dan pertumbuhan tunas optimal pada perlakuan dosis $40 \mathrm{~kg}$ ha/tahun. Datta (tanpa tahun), menggunakan NPK untuk memupuk murbei dengan perbandingan N 15: P 15: K 15. Berdasarkan uraian tersebut dapat diketahui bahwa pupuk yang memiliki bahan dasar unsur hara makro (seperti: nitrogen dan sulfur) dapat meningkatkan kualitas daun murbei.

Salah satu pupuk anorganik yang memiliki kandungan nitrogen dan sulfur tinggi yaitu pupuk ZA. Oleh karena itu diperlukan upaya penambahan nitrogen dan sulfur menggunakan pupuk ZA untuk meningkatkan kualitas tanaman murbei sehingga dapat mendorong pertumbuhan dan perkembangan ulat sutera alam (B. mori).

\section{Metode Penelitian}

Jenis penelitian ini adalah deskriptif kuantitatif. Pelaksnaan penelitian yaitu pada bulan Juli-Oktober 2014. Tempat pelaksanaan penelitian yaitu di Instalasi Kebun Agrotechnopark Universitas Jember di Jubung Jember. Perlakuan pupuk ZA pada stek murbei dilakukan selama 3 bulan pada bulan JuliAgustus 2014. Pelaksanaan pemeliharaan ulat sutera alam (B. mori) dilakukan pada bulan SeptemberOktober 2014.

Bahan yang digunakan dalam penelitian ini meliputi: polybag berwarna hitam ukuran 40x60 $\mathrm{cm}^{2}$, media tanam, stek murbei dengan 4 mata tunas dan memiliki diameter $1,5-2 \mathrm{~cm}$ sebanyak 640 stek, pupuk ZA, telur ulat sutera alam (B. mori) ras C-301, dan tanaman murbei (M. multicaulis). Penyiapan perlakuan pupuk ZA yaitu pupuk ZA ditimbang dengan menggunakan timbangan analitik (Ohauss) dengan dosis sebesar 6,25 g; 12,5 g; 18,75 g. Pupuk diberikan pada tanaman setelah berusia 1 bulan dari penanaman. Daun murbei yang diberikan pada ulat sutera yaitu daun murbei yang telah berumur 3 bulan dari penanaman. Ulat sutera alam diberi 4 macam perlakuan yaitu kontrol, pakan dengan dosis pupuk 6,25 g/polybag, 12,5 g/ polybag, dan 18,75 g/polybag dengan 4 kali ulangan. Jumlah ulangan berisi 20 larva.

Ruangan yang digunakan untuk pemeliharaan ulat sutera alam (B. mori) disterilkan menggunakan formalin $2 \%$ selama 24 jam dalam kondisi tertutup, dan kemudian dibuka. Ruangan dibuka selama 7 hari dan dapat digunakan untuk pemeliharaan ulat sutera alam (Prihatin, 2010). Variabel yang diamati dan dihitung dalam penelitian ini yaitu variabel pertumbuhan di antaranya yaitu berat kokon, panjang kokon, dan diameter kokon. Analisis data menggunakan One-way analsys of varians (ANOVA) dan selanjutnya jika berbeda nyata dilakukan uji Duncan.

\section{Hasil Penelitian}

Berdasarkan hasil pengamatan pemberian pupuk ZA pada tanaman murbei terhadap kokon ulat sutera alam (B. mori), rerata berat kokon tertinggi yaitu pada P3 (18,75 g/polybag) dengan rerata $1,91 \mathrm{~g}$, terendah pada kontrol dengan rerata 1,65 g. Rerata panjang kokon tertinggi pada P3 $(18,75 \mathrm{~g} /$ polybag) dengan rerata $3,35 \mathrm{~cm}$, terendah pada kontrol dengan rerata $3,21 \mathrm{~cm}$. Rerata diameter kokon tertinggi pada P3 (18,75 g/polybag) dengan rerata $2,08 \mathrm{~cm}$ dan terendah pada kontrol dengan rerata $1,93 \mathrm{~cm}$ (Tabel 1). 
Tabel 1 Pengaruh pemberian pupuk ZA pada tanaman murbei terhadap kokon $B$. mori

\begin{tabular}{lllll}
\hline \multirow{2}{*}{ Variabel pengamatan } & \multicolumn{4}{c}{ Perlakuan (ZA/polybag) } \\
\cline { 2 - 5 } & \multicolumn{1}{c}{ Kontrol } & $\mathbf{6 , 2 5}$ gram & $\mathbf{1 2 , 5}$ gram & $\mathbf{1 8 , 7 5}$ gram \\
\hline Berat kokon $(\mathrm{g})$ & $1,65 \pm 0,2^{\mathrm{a}}$ & $1,74 \pm 0,2^{\mathrm{ab}}$ & $1,84 \pm 0,2^{\mathrm{bc}}$ & $1,91 \pm 0,2^{\mathrm{c}}$ \\
Panjang kokon $(\mathrm{cm})$ & $3,21 \pm 0,3^{\mathrm{a}}$ & $3,29 \pm 0,2^{\mathrm{ab}}$ & $3,29 \pm 0,2^{\mathrm{ab}}$ & $3,35 \pm 0,2^{\mathrm{b}}$ \\
Diameter kokon $(\mathrm{cm})$ & $1,93 \pm 0,1^{\mathrm{a}}$ & $2,00 \pm 0,1^{\mathrm{ab}}$ & $2,01 \pm 0,2^{\mathrm{ab}}$ & $2,08 \pm 0,2^{\mathrm{b}}$ \\
\hline
\end{tabular}

Keterangan: Angka yang diikuti dengan huruf yang sama pada kolom yang sama menunjukkan hasil tidak berbeda nyata pada uji Duncan $(0,05)$.

\section{Pembahasan}

Berdasakan hasil penelitian, pemberian pupuk ZA pada tanaman murbei berpengaruh terhadap berat kokon, panjang kokon dan diameter kokon ulat sutera alam (B. mori). Dari hasil uji ANOVA, dapat diketahui perlakuan pupuk ZA pada tanaman murbei berpengaruh sangat signifikan terhadap berat kokon $B$. mori. Hal ini dikarenakan pemberian pupuk ZA pada tanaman murbei, akibatnya jumlah protein dalam tanaman murbei meningkat. Asupan protein dari pupuk ZA ini yang berpengaruh terhadap penambahan berat kokon. Pupuk ZA merupakan pupuk anorganik yang mengandung senyawa sulfur (24\%) dalam sulfat serta Nitrogen (21\%) dalam bentuk amonium (Kiswondo, 2011). Nitrogen merupakan unsur hara utama bagi pertumbuhan tanaman karena penyusun dari semua protein (Nugraha, 2010). Apabila unsur nitrogen yang tersedia lebih banyak, maka akan dihasilkan protein yang lebih banyak dan daun tumbuh lebih lebar, akibatnya proses fotosintesis akan lebih banyak (Sarief, 1989). Apabila daun murbei tumbuh lebih lebar dan banyak mengandung protein, maka daun tersebut dapat menjadi asupan pangan yang baik untuk ulat sutera alam (B. mori). Menurut Hagen et al., (1984) nitrogen $(\mathrm{N})$ mempunyai peran sentral pada semua proses metabolisme serta pengkodean genetik, sehingga kualitas dan kuantitas $\mathrm{N}$ daun pakan (protein/asam amino) umumnya akan membatasi pertumbuhan dan perkembangan serangga

Selain nitrogen, kandungan penting dalam pupuk ZA yaitu sulfur. Sulfur juga berperan dalam pembentukan klorofil serta beberapa reaksi metabolisme seperti karbohidrat, lemak, dan protein (Tisdale et al., 1985). Sulfur merupakan penyusun dari 21 asam amino yang membentuk protein (Winarso, 2005). B. mori membutuhkan protein dalam pembentukan kokon. Komposisi kulit kokon antara lain yaitu fibroin 62-67\%, serisin $22-25 \%$, air $10-11 \%$, dan garam mineral $1-1 \frac{1}{2} \%$ (Lembaga Pengembangan Ekonomi (LPE) AlSyura, 2003). Komponen fibroin antara lain yaitu isoleusin, alanin, valin, prolin, leusin, fenilalanin, serin, treonin, tirosin, kelompok karboksi dari aspartat dan glutamat (Sah et al., 2010), namun hanya terdapat beberapa asam amino yang berperan penting dalam penyusunan fibroin, di antaranya yaitu serin, glisin, alanin, dan tirosin (Matei et al., 2006). Dengan demikian tanaman murbei yang diberi pupuk ZA memiliki kandungan protein yang lebih banyak. Tanaman murbei tersebut digunakan sebagai bahan pakan ulat sutera alam (B. mori), akibatnya protein pada $B$. mori semakin meningkat dan kualitas kokon yang dihasilkan menjadi semakin baik.

\section{Pengaruh Tanaman Murbei yang diberi Pupuk ZA terhadap Panjang Kokon}

Berdasarkan hasil uji ANOVA, diketahui bahwa tidak ada pengaruh pemberian pupuk ZA pada tanaman murbei terhadap panjang kokon B. mori. Hasil penelitian menunjukkan rerata panjang kokon paling tinggi yaitu pada perlakuan pupuk ZA dengan dosis sebesar 18,75 g/polybag (perlakuan 3/P3). Rerata panjang larva terendah yaitu pada kontrol (tanpa perlakuan pupuk ZA). Hal ini dikarenakan beberapa faktor, di antaranya yaitu faktor yang berasal dari ulat itu sendiri seperti nafsu makan ulat berkurang serta spesies ulat yang dibudidayakan berbeda. Akibatnnya setiap spesies ulat memiliki ukuran masing-masing. Ukuran tersebut merupakan ciri-ciri dari setiap ras ulat sutera alam (B. mori). 
2. Pengaruh Tanaman Murbei yang diberi Pupuk ZA terhadap Diameter Kokon

Berdasarkan hasil uji ANOVA dapat diketahui adanya pengaruh pemberian pupuk ZA pada tanaman murbei terhadap diameter kokon $B$. mori. Setiap kokon memiliki diameter yang berbeda-beda. Perbedaan diameter pada tiap kokon menjadi ciri khas spesies ulat sutera alam (B. mori). Ulat sutera alam yang digunakan pada penelitian ini yaitu hasil persilangan ulat sutera alam ras Cina dengan ras Jepang. Hasil persilangan tersebut yaitu kokon berbentuk lonjong dan ada juga yang berlekuk di bagian tengah-tengah kokon.

Dari hasil penelitian diketahui bahwa, pada perlakuan kontrol memiliki ukuran sedang dengan rerata $6,2 \mathrm{~cm}^{2}, P 1(6,25 \mathrm{~g} /$ polybag $)$ berukuran sedang dengan rerata $6,6 \mathrm{~cm}^{2}, \mathrm{P} 2(12,5 \mathrm{~g} /$ polybag $)$ berukuran sedang dengan rerata $6,5 \mathrm{~cm}^{2}$, dan P3 $(18,75 \mathrm{~g} /$ polybag) berukuran sedang dengan rerata $7,0 \mathrm{~cm}^{2}$. Rerata ukuran kokon tertinggi yaitu P3 $(18,75 \mathrm{~g} /$ polybag). Hal ini karena tanaman murbei yang digunakan sebagai pakan ulat sutera alam $(B$. mori) mendapatkan asupan nitrogen dan sulfur secara optimal dari pemupukan tersebut. Sehingga kandungan nitrogen dan sulfur dalam tanaman murbei meningkat. Apabila tanaman murbei memiliki kandungan nitrogen dan sulfur yang tinggi, maka juga akan memiliki kandungan protein yang tinggi.

Hal ini karena nitrogen merupakan unsur hara utama untuk pertumbuhan tanaman, sebab nitrogen merupakan penyusun protein (Nugraha, 2010). Sulfur merupakan penyusun dari 21 asam amino pembentuk protein (Winarso, 2005). Pembentukan kokon dipengaruhi oleh protein dari dalam tubuh ulat sutera alam, dengan adanya stimulus tambahan protein dari luar menyebabkan komponen protein di dalam tubuh ulat bertambah. Akibatnya metabolisme di dalam tubuh juga meningkat, sehingga kualitas kokon yang terbentuk semakin bagus. Oleh karena itu pada P3 (18,75 g/ polybag) ulat sutera alam mampu menghasilkan rerata diameter kokon tertinggi.

\section{Kesimpulan}

Pemberian pupuk ZA pada tanaman murbei berpengaruh signifikan terhadap berat kokon dan diameter kokon. Perlakuan pupuk ZA yang maksimal untuk berat, panjang dan diamater kokon yaitu pada P3 dengan dosis pupuk 18,75 g/polybag. Hal ini berdasarkan pada hasil penelitian yang menunjukkan bahwa rerata berat kokon, panjang kokon, dan diameter kokon tertinggi yaitu pada P3 (18,75 g/polybag). Sehingga pemberian dosis pupuk ZA yang maksimal pada tanaman murbei sebagai pakan ulat sutera alam untuk menghasilkan kokon yaitu pada P3 (18,75 g/polybag).

\section{Ucapan Terima Kasih}

Terima kasih kepada Dirjen Dikti atas suport pendanaan penelitian ini dari Hibah Penelitian Fundamental Tahun 2014 Nomor: 413/UN25.3.1/ LT.6/2014 tanggal 03 Maret 2014.

\section{Daftar Pustaka}

Atmosoedarjo, Kartasubrata, Kaomini, Saleh, Moerdoko, Pramoedibyo, dan Ranoeprawiro. (2000). Sutera Alam Indonesia. Jakarta: Yayasan Sarana Wana Jaya.

Datta, R. K. Tanpa Tahun. Mulberry Cultivation and Utilization in India. India: FAO Electronic Conference on Mulberry for Animal Production (Morus1-L).

Hagen KS, Dadd RH dan Reese J. (1984). The Food of Insect in CB Huffaker and R.L. Rabb (Eds). Ecological Entomology. New York: John Wiley and Sons.

Kiswondo, S. (2011). Penggunaan Abu Sekam dan Pupuk ZA terhadap Pertumbuhan dan Hasil Tanaman Tomat (Lycopersium esculentum Mill.). Embryo, 8 (1).

Lembaga Pengembangan Ekonomi (LPE) Al-Syura. (2003). Laporan Akhir Kegiatan Penelitian Pengembangan Komoditi Pertanian Unggulan di Kabupaten Garut. Garut.

Matei, A., Tanase, D.B., Diaconescu, C., Constantinescu, M., dan Dolis, M. (2006). Contributions 
to the Study of the Leaf Protein Value in Different Mulberry Varieties. Archiva Zootechnica. Vol. 9.

Nugraha, Y. M. (2010). Kajian Penggunaan Pupuk Organik dan Jenis Pupuk N terhadap Kadar N Tanah, Serapan N dan Hasil Tanaman Sawi (Brassica juncea L.) pada Tanah Litosol Gemolong. Surakarta: Universitas Sebelas Maret.

Nuraeni S, dan Putranto B. (2007). Aspek Biologis Ulat Sutera (Bombyx Mori L.) dari Dua Sumber Bibit di Sulawesi Selatan. Jurnal Perennial, 4 (1): 10-17.

Prihatin J. (2010). Sains Polusi Dampak Hujan Asam terhadap Budidaya Ulat Sutera. Malang: UMM Press.

Rahmayanti, S. dan Sunarto. (2008). Pengaruh Pemberian Limbah Pemeliharaan Ulat Sutera terhadap Produksi Daun Murbei. Jurnal Penelitian dan Konservasi Alam. Vol. V (5): 451-459.

Sah, M. K., Kumar, A., dan Pramanik, K. (2010). The Extraction of Fibroin Protein From Bombyx Mori Silk Cocoon: Optimization of Process Parameters. International Journal of Bioinformatics Research. Vol. 2 (2): 33-41.

Sarief, S. E. (1989). Kesuburan dan Pemupukan Tanah Pertanian. Bandung: Pustaka Buana.

Setiadi, W., Kasno, dan Haneda, N. F. (2011). Penggunaan Pupuk Organik untuk Peningkatan Produktivitas Daun Murbei (Morus sp.) Sebagai Pakan Ulat Sutera (Bombyx mori L.). Jurnal Silvikultur Tropika. Vol. 2 (3): 165-170.

Tisdale S.L, Nelson W.L, and Beaton J.D. (1985). Soil Fertility and Fertilizers. 4th ed. New York: MacMillan Publishing Company.

Widiyaningrum, P. (2009). Growth Performance and Cocoon Production of Silkworm (Bombyx mori L.) on Different Frequency of Feeding and Age of Leaves. Berk. Penel. Hayati. Vol. 15:17-20.

Winarso, S. (2005). Kesuburan Tanah Dasar Kesehatan dan Kualitas Tanah. Jogjakarta: Gava Media. 